\title{
The use of naked oat instead of barley in complete feed for fatteners
}

\author{
M. Fabijańska and M. Bekta \\ Department of Animal Feeding and Feed Science, \\ Warsaw Agricultural University \\ Rakowiecka 26/30, 02-528 Warsaw, Poland
}

\begin{abstract}
In an experiment carried out on 3 groups of fatteners, the effect of a high proportion of naked oat $(55 \%)$ and the addition of synthetic zeolite $(3 \%)$ on production results was studied. The control group received a mixture with $55 \%$ barley. The fatteners receiving the oat without added zeolite had the highest body weight gains $(855 \mathrm{~g})$ and the best feed efficiency $(2.81 \mathrm{~kg}$ per $1 \mathrm{~kg})$, but the differences were not statistically significant. The addition of zeolite caused a significant increase of digestibility coefficients of all nutrients. Zeolite also improved the indices of nitrogen balance, expressed by significantly smaller excretion of nitrogen with faeces and higher nitrogen retention in fatteners at $70 \mathrm{~kg}$ body weight.
\end{abstract}

KEY WORDS: naked oat, zeolite, fatteners, digestibility, $\mathrm{N}$ balance, gains

\section{INTRODUCTION}

In spite of their many benefits, oats are used in pig feeding to a very small extent. This limitation results from the high level of crude fibre and a low energy value of oat grain. The naked oat variety Akt developed by Polish breeders was registered recently (1997). This variety meets all of the requirements of a feed suitable for pigs and poultry. Due to its content of about $2 \%$ crude fibre and $6 \%$ fat, Akt has a digestibility and energy value (about 14 MJ EM) equal to that of maize and wheat. Furthermore, it contains about $14 \%$ protein (in dry matter) with a better amino acid composition than the two above-mentioned cereals (Kosieradzka, 1999; Kosieradzka and Fabijańska, 1999; Nita, 1999). Naked oat varieties are known and cultivated worldwide, but Akt is the first Polish variety and there are only a few studies on the use of this cereal in animal nutrition. 
The aim of the present study was to examine the suitability of the naked oat variety Akt for pig fattening via determination of digestibility, nitrogen balance, and production indices, i.e., body weight gain and feed consumption. The effect of adding synthetic zeolite on the studied production parameters was also examined.

\section{MATERIAL AND METHODS}

The studies were conducted with 24 crossbred fatteners [ $q$ (Polish Large White $\mathrm{x}$ Polish Landrace) $\mathrm{x} \delta$ (DxP)], divided into 3 groups, based on analogs, with the consideration of equal representation of $\operatorname{sex}(4+$ and $4 \delta)$. The animals were fed individually throughout the whole experimental period with complete feed mixed with water at a 1:1 ratio. Feed quantity was increased every 2 weeks. The composition of the mixtures (Table 1) of the experimental groups (II and III) contained $55 \%$ naked oat meal; group III additionally received $3 \%$ synthetic zeolite. The mixture for the control group contained barley instead of oat $(55 \%)$. The energy value of the experimental mixtures was somewhat higher due to the higher energy value of the naked oat. During the experiment, the animals were weighed several times and the consumption of the feeds was also recorded.

Fattening was conducted from $27 \mathrm{~kg}$ to $105 \mathrm{~kg}$ body weight. Daily body weight gains, feed intake, and energy and protein intake per $\mathrm{kg}$ of gain were determined.

TABLE 1

Composition and nutritive value of the mixtures fed to pigs from 27 to $105 \mathrm{~kg}$ body weight, \%

\begin{tabular}{|c|c|c|c|}
\hline \multirow{2}{*}{ Specification } & \multicolumn{3}{|c|}{ Group } \\
\hline & I & II & III \\
\hline Barley meal & 55.00 & - & - \\
\hline Wheat meal & 30.00 & 30.00 & 27.00 \\
\hline Naked oat meal & - & 55.00 & 55.00 \\
\hline Concentrate $\mathrm{T}^{1}$ & 15.00 & 15.00 & 15.00 \\
\hline Zeolite $^{2}$ & - & - & \\
\hline \multicolumn{4}{|l|}{ In $1 \mathrm{~kg}$ of mixture } \\
\hline ME MJ* & 11.85 & 12.76 & 12.38 \\
\hline crude protein, $\mathrm{N} \times 6,25 \mathrm{~g}$ & 161 & 161 & 158 \\
\hline lysine, $\mathrm{g}$ & 7.10 & 7.35 & 7.25 \\
\hline \multicolumn{4}{|c|}{$\begin{array}{l}\text { * energetic value of the mixtures was calculated basing on the regression equations of Hoffmann an } \\
\text { Schiemann (1980) and Miller and Kirchgessner (1983), as cited in Nutrient Requirements of Pig } \\
\text { (1993) } \\
2 \text { concentrare for fatteners } \\
2 \text { synthetic zeolite }\end{array}$} \\
\hline
\end{tabular}


The digestibility of the feeds and nitrogen balance were determined on three about $70 \mathrm{~kg}$ hogs from each group.

The results were subjected to statistical analysis using the Statgraphics Plus program.

\section{RESULTS AND DISCUSSION}

The best production results were obtained in group II receiving $55 \%$ of naked oat in the mixture (Table 2). It had the highest body weight gains and the lowest consumption of feed, protein and energy per $\mathrm{kg}$ of gain. In the group with the addition of zeolite, the production results were almost the same as in the control

TABLE 2

The effect of naked oat and barley diets on growth performance of pigs

\begin{tabular}{lccc}
\hline Specification & \multicolumn{3}{c}{ Group } \\
\cline { 2 - 4 } & $\mathrm{I}(\mathrm{n}=8)$ & $\mathrm{II}(\mathrm{n}=8)$ & $\mathrm{III}(\mathrm{n}=8)$ \\
\hline Initial body weight, $\mathrm{kg}$ & 26.9 & 26.23 & 27.90 \\
Final body weight, $\mathrm{kg}$ & 103.7 & 110.75 & 101.75 \\
Daily gains, $\mathrm{g}$ & 784 & 855 & 789 \\
& & & \\
Intake per l kg of gain & 3.16 & 2.81 & 3.03 \\
complete fecd, $\mathrm{kg}$ & 508 & 446 & 493 \\
crude protein, g & 36.37 & 35.05 & 38.78 \\
ME, MJ & & & \\
\hline
\end{tabular}

group. In spite of visibly better production results in group II as compared with groups I and III, these differences were not statistically proven. The production results in group II are consistent with those obtained by Friendt et al. (1988) who found the highest daily gains in fatteners fed a mixture with $50 \%$ naked oat, recognizing simultaneously this level as optimal for pigs. In the experiments of Myer et al. (1985) a 79\% proportion of oat in the mixture did not lower gains or feed utilization by the fatteners. Similarly, Morris and Burrows (1986) did not observe deterioration of feed utilization by fatteners even in case of a $96.7 \%$ proportion of naked oat in the mixture. Kosieradzka and Fabijańska (1999) found that a $98 \%$ proportion of the naked oat in the diets of fatteners lowered gains and deteriorated feed utilization in comparison with a $30 \%$ proportion of this cereal in the mixture.

In the group of fatteners receiving the mixture with added zeolite, the daily gains were the same as in the control group and somewhat lower than in the 
group without zeolite but the same oat proportion; these differences were not statistically significant. The results of Wetserek (after Korol, 1995) who found higher gains (by $7 \%$ ) and improved feed utilization (by $6.5 \%$ ) when $3 \%$ zeolite was added to fatteners' feed were not confirmed.

The fatteners fed the mixtures with oat digested feed better, although the differences between group II and the control were insignificant (Table 3). On the other hand, the addition of zeolite increased the digestibility coefficients of all

TABLE 3

The effect of naked oat on nutrient total digestibility and $\mathrm{N}$ balance in $70 \mathrm{~kg}$ pigs

\begin{tabular}{|c|c|c|c|}
\hline \multirow{2}{*}{ Specification } & \multicolumn{3}{|c|}{ Group } \\
\hline & $I(n=4)$ & II $(n=4)$ & III $(n=4)$ \\
\hline Digestibility coefficients, $\%$ & & - & - \\
\hline organic matter & $80.35^{\mathrm{A}}$ & 83.17 & $86.69^{\mathrm{B}}$ \\
\hline crude protein & $75.11^{\mathrm{A}}$ & 80.58 & $84.02^{8}$ \\
\hline crude fat & $50.20^{\wedge}$ & 68.20 & $78.99^{B}$ \\
\hline crude fibre & $28.25^{\mathrm{A}}$ & 26.30 & $35.64^{\mathrm{B}}$ \\
\hline $\mathrm{N}$-free extractives & $86.81^{A}$ & 88.62 & $90.66^{\mathrm{B}}$ \\
\hline \multicolumn{4}{|l|}{ Nitrogen balance } \\
\hline $\mathrm{N}$ intake, $\mathrm{g}$ & 58.48 & 62.44 & 61.67 \\
\hline $\mathrm{N}$ in faeces, $\mathrm{g}$ & $14.56^{A}$ & 12.16 & $9.86^{\mathrm{B}}$ \\
\hline $\mathrm{N}$ digested, $\mathrm{g}$ & $43.92^{\wedge}$ & $50.28^{B}$ & $51.82^{13}$ \\
\hline $\mathrm{N}$ in urine, $\mathrm{g}$ & $18.31^{\mathrm{a}}$ & $24.22^{\mathrm{b}}$ & $17.66^{a}$ \\
\hline$N$ retention, $\mathrm{g}$ & $25.61^{\mathrm{a}}$ & $26.06^{\mathrm{a}}$ & $34.16^{b}$ \\
\hline \multicolumn{4}{|l|}{$\mathrm{N}$ retention, $\%$} \\
\hline $\mathrm{N}-$ intake & $43.80^{\mathrm{a}}$ & $41.79^{\circ}$ & $55.39^{\text {bd }}$ \\
\hline $\mathrm{N}$ - digested & $58.22^{a}$ & $51.86^{\mathrm{c}}$ & $65.93^{\text {bd }}$ \\
\hline
\end{tabular}

components of the mixture and the differences in relation to group I were highly significant. A positive influence of zeolite on the processes occurring in the alimentary tract of animals has been confirmed by many authors in their studies (Cheshmedzhiev et al., 1984; Tkachev et al., 1985; Korol, 1995; Dias et al., 1998). This is exerted by the neutralizing action on toxic substances in the alimentary tract, increased activity of digestive enzymes, increased resistance to diarrhoea, which contribute to improved digestibility. The results of nitrogen balance confirmed the favourable effect of zeolite, manifested by smaller quantities of nitrogen excreted with faeces-the difference was highly significant as 
compared with the control group. Both groups of animals receiving oat in their mixtures demonstrated significantly higher levels of digested nitrogen in comparison with the control group. On the other hand, the highest quantities of nitrogen in urine were found in group II and this was a result significantly higher as compared with the control group and group III, receiving zeolite. The greatest quantity of nitrogen was retained in the group with added zeolite and the difference, in comparison with the results of groups I and II, was significant. The indices, expressed as a ratio of retention to the intaken and digested nitrogen were also significantly higher in the group receiving zeolite as compared with the remaining groups in this experiment. The effect of zeolite on improving the nitrogen balance indices may result from the fact that it prolongs the passage time of a feed in the alimentary tract, which, in turn, improves absorption. Moreover, zeolite binds ammonia in the small intestine, preventing its toxic effects, and reduces excretion of nitrogen together with urine (Cheshmedzhiev et al., 1984; Korol 1995; Dias et al., 1998).

Despite better digestibility and higher nitrogen balance indicators in group III fatteners receiving zeolite, this additive improved the production performance of these animals (Table 2). This can be explained by the fact that the physiological indicators were determined only once in half of the animals at a body weight of $70 \mathrm{~kg}$ ( on ${ }^{\star}$ ), while the production indicators were calculated for the entire experimental period. It can not be excluded that the effects of zeolite differ depending on the age of the animals.

\section{CONCLUSIONS}

The naked oat is a good component of complete feed for fatteners. Its use at a proportion of $55 \%$ in the composition of a mixture leads to good production results for fatteners (daily body weight gains of $855 \mathrm{~g}$ and feed utilization of $2.8 \mathrm{~kg} / \mathrm{kg}$ of gain). These results are even somewhat better than those for fatteners from the control group, fed a mixture with the same proportion of barley.

The addition of zeolite in an amount of $3 \%$ improves digestibility and nitrogen balance indices in $70 \mathrm{~kg}$ fatteners. It does not, however, affect the production results of animals over the entire period of fattening, which remain at control group levels. 


\section{REFERENCES}

Cheshmedzhiev B.V., Angelov A., Nestorov N., Kristev A., Bakalivanov S., Chesmedzhieva R., 1984. Effect of zeolite in the feeding of pregnant and nursing sows and sucking piglets. Zhivot. Nauki 23 (5), 73-78

Dias J., Huclvan C., Dinis M.T., Matailler R., 1998. Influence of dietary bulk (silica, cellulose and natural zeolite) on protein digistibility, growth, feed intake and feed transit time in European seabass (Dicentrarchus labrax) juveniles. Aquat. Living Resour. 11, 219-226

Friend D.V., Fortin A., Poste L.M., Butler G., Kramer J.K.G., Burrows V.D., 1988. Feeding and metabolism trials and assessment of carcass and meet quality to growing finishing pigs fed naked oats (Avena nuda). Can. J. Anim. Sci. 68,511-521

Korol W., 1995. Feed Additives for Pigs. The Kielanowski Institute of Animal Physiology and Nutrition (Editor). Jabłonna (Poland)

Kosieradzka I., 1999. Evaluation of the possibilities to applied Polish naked oat grain in feeding of monogastric animals (in Polish). PhD Thesis, Warsaw Agricultural University Press, Warszawa (Poland)

Kosieradzka I., Fabijańska M., 1999. Polish naked oats in the intensive pig fattening. XXVIII Session of Animal Nutrition Commission, Committee of Animal Sciences, Polish Academy of Sciences: Nutritional Needs of Higl-Productive Farm Animals. Krynica (Poland), pp. 259-262

Kosicradzka I., Fabijańska M., Łozicki A., Siedlecki J., 1999. Application of Polish variety of naked oats Akt in feeding of fatteners. Conference: Current Problems of Breeding, Health and Production of Swine. Ceske Budejovice (Czech Republic)

Myer R.O., Barnett R.D., Walker W.R., 1985. Evaluation of hull-less oats (Avena nuda L.) in diets for young swine. Nutr. Rep. Int. 32, 1273-1277

Morris J.R., Burrows V.D., 1986. Naked oats in grower-finisher pig diets. Can. J. Anim. Sci. 66, 833836

Nita Z.T., 1999. Current situation and new directions of oats cultivation of Poland (in Polish). Food 1 (18), Suppl., 186-192

Nutrient Requirements of Pigs. Nutritive Value of Feedstuffs (in Polish), 1993. The Kielanowski Institute of Animal Physiology and Nutrition (Editor). Jabłonna (Poland)

Tkachev E.Z., Ustin V.V., 1985. Digestive and metabolic functions of the digestive tract of young pigs given a feed mixture containing natural zeolite (in Russian). Doklady Vasklnnil. 3, 33-35

\section{STRESZCZENIE}

\section{Owies nagi jako zamiennik jęczmienia w mieszankach pełnodawkowych dla tuczników}

W doświadczeniu przeprowadzonym na 3 grupach tuczników badano wpływ dużego udziału owsa nagiego (55\%) oraz dodatku zeolitu syntetycznego (3\%) na wyniki produkcyjne. Grupa kontrolna (I) dostawała mieszankę $z$ jęcznieniem w ilości $55 \%$. Tuczniki otrzymujące owies bez dodatku zeolitu (I) miały najwyższe przyrosty $(855 \mathrm{~g})$ oraz najlepiej wykorzystywał paszę $(2.81 \mathrm{~kg} / 1 \mathrm{~kg}$ przyrostu), różnice nie zostały jednak potwierdzone statystycznie. Dodatek zeolitu spowodował istotny wzrost współczynników strawnoścj wszystkich składników micszanki u tuczników przy masic ciała $70 \mathrm{~kg}$. Zeolit poprawił także wskaźniki bilansu azotu. Nie miało to jednak wpływu na wielkość przyrostów masy ciała i zużycie paszy/kg przyrostu za cały okres tuczu, które były podobne do wyników grupy kontrolncj. 